\title{
BOARDING THE EURO PLANE: EURO ADOPTION IN THE CZECH REPUBLIC AND SLOVAKIA
}

\author{
Assem Dandashly Maastricht University \\ and \\ Amy Verdun University of Victoria
}

\begin{abstract}
What explains euro adoption strategies in the Czech Republic and Slovakia? How have each of these two countries performed under the regime they joined (Czech Republic: flexible exchange rates; Slovakia: in the euro area)? How has that experience affected Czech and Slovak policies towards euro adoption and their performance during the euro crisis? This paper asks these questions and seeks to give an answer to the question of why Slovakia adopted the euro while the Czech Republic did not. We address these questions by taking an eclectic approach that draws on constructivism, domestic politics, and political economy. The paper examines five explanations based on these theoretical approaches: the inferiority-superiority factor; European identity and the "return" to Europe; the symbolic factor of the currency; euroskepticism; and economic structure and trade relations. We find that each of the five explanations enriches our insight into these matters. But if forced to choose, we find that an explanation drawn on a domestic politics approach contributes the most to our overall understanding of euro adoption policies in the two cases.
\end{abstract}




\section{Introduction}

Following the Velvet Divorce of January 1, 1993, Czechoslovakia was separated into two sovereign countries: the Czech Republic and Slovakia. The Velvet Divorce served as a critical juncture that influenced institutional development in the Czech Republic and Slovakia for the two decades that followed. Regardless of the different reform tracks both countries took, they managed to meet the acquis communautaire and be amongst the eight Central and East European Countries (CEECs) to join the European Union (EU) on May 1, 2004. In so doing, they committed to adopting the euro sometime in the future, that is, once they met the convergence criteria. Until that time, they would remain member states with a derogation. ${ }^{1}$ Slovakia, the smaller of the two, adopted the euro on January 1, 2009. The Czech Republic meets many of the convergence criteria, but has not taken serious strides towards adopting the euro.

The questions this paper seeks to answer are: Why is it that two countries, which used to be one, ended up having very different policies regarding euro adoption? Why did Slovakia adopt the euro while the Czech Republic did not? How has each country coped with the financial crisis, given their policy choices? In order to join the euro, countries need to meet the so-called "convergence criteria." "However, these criteria can be best met if institutions are adapted to them and if domestic politics are conducive to making major political, institutional, and economic changes.

The bulk of this paper seeks to explain euro adoption strategies in the Czech Republic and Slovakia up to 2010. The second part of the paper examines how each country performed under the regime they joined (Czech Republic: flexible exchange rates; Slovakia: in the euro area) and examines how that experience affected Czech and Slovak policies towards euro adoption and their performance during the euro crisis. ${ }^{3}$ The paper moves beyond an economic cost-benefit analysis, since it cannot give a full picture regarding the decisions on euro adoption in both countries. Moreover, for an open, small, export-based economy with a small domestic market, as is the case with both the Czech Republic and Slovakia, some would argue that it would be in the economic interest of these countries to join the euro area as soon as possible. Indeed, the National Bank of Slovakia and Slovak economists believed the advantages of euro adoption would outweigh the costs (personal interview by the authors with an official from the National Bank of Slovakia, Bratislava, November 23, 2009). While the economic explanation might be able to shed some light on the euro adoption strategy in the case of Slovakia, it cannot tell us much about the Czech case, because in that country, there was not the same push for euro adoption.

To answer the main research questions, the paper examines five possible explanations. Three of these are loosely based on constructivism and symbolism: (1) the inferiority-superiority factor; (2) European identity and the "return" to Europe; and (3) the symbolic factor of the currency. The fourth is derived from a domestic politics approach: (4) the role of national elites and euroskepticism. The fifth explanation builds on the political economy literature: (5) economic structure and trade relations. The paper discusses these explanations: first, in order to understand

\footnotetext{
${ }^{1}$ Article 4 of the Treaty of Accession stipulates that "Each of the new Member States shall participate in Economic and Monetary Union from the date of accession as a Member State with a derogation within the meaning of Article 122 of the EC Treaty," Official Journal of the European Union, 2003; see also Article 140 of the Treaty on the Functioning of the European Union (TFEU).

${ }^{2}$ These criteria refer to inflation and interest rates, budgetary deficit and public debt, and the independence of the central bank; see Article 126 TFEU and Protocol 13 TFEU (and footnote 4 below for more details).

${ }^{3}$ This paper is based on elite face-to-face interviews held during 2009 in the Czech Republic and Slovakia.
} 
the euro adoption outcome in both countries; second, to analyze the performance of both countries during the euro crisis; and third, to highlight which of the five explanations can help us best understand the euro adoption policies in both countries. Although we find that we can learn something from each of the five explanations, we find the fourth explanation, the one based on a domestic politics approach, to be the most helpful in understanding euro adoption strategies.

The next section lays down the analytical framework of the paper. The paper will then analyze the various possible explanations regarding euro adoption in the Czech Republic and Slovakia and discuss the effects of the euro crisis. We conclude by highlighting the main findings, including a brief discussion of what theoretical perspective best explains the results.

\section{Framework for the Analysis and Hypotheses}

Slovakia's road towards the EU was not easy, given its historically underprivileged situation while part of the former Czechoslovakia, and even later, during Prime Minister Vladimír Mečiar's term in office. This disadvantaged position pushed Slovakia to be among the last countries (from the group that joined in May 2004) to sign the accession agreement. Following that, Slovakia managed to move quickly through the reform process, joining the EU and also the euro area soon after. Drawing on constructivism, a domestic politics approach, and political economy literature, we seek to obtain a better understanding as to why Slovakia joined the euro area while the Czech Republic did not.

\section{European Identity and Symbolism}

Issues of identity, the role of ideas, and the usage of money as a symbol have often been ignored by political scientists studying euro accession strategies (exceptions are Dyson 2007; Johnson 2008). Constructivists emphasize how ideas and identities are created, how they evolve, and how they shape the way states interpret and react to their situation. Since the introduction of the euro and the expansion of the euro area eastwards, ideas and identities have been influencing the attitudes of euro area citizens and the way they identify themselves in European or national terms (Walt 1998; Risse 2003).

Since the end of the Cold War, the Europeanization process has affected decisions and politics of all New Member States (NMS). Various scholars point to a fast trend of institutional development that has been going on due not only to EU incentives, but also to a social learning process (see Checkel 2001; Schimmelfennig and Sedelmeier 2004, 2005). The effect of social learning and incentives can change due to issue area, time, and different circumstances. It became easier to evaluate these factors especially after May 1, 2004, when the NMS joined the EU. Central banks are among the institutions that underwent changes and institutional developments and were affected by this trend. Among the main beliefs transferred to CEECs is the importance of "protecting price stability" and of central bank independence in the transformation process, both of which are considered "key to economic development in democratic states" (Johnson 2006, 363).

Despite the importance of this social learning process that was taking place, involving international players and creating some epistemic communities (Haas 1992; Verdun 1999), this argument may not be able to explain the whole story. Domestic circumstances must be conducive to the changes that will accompany such a development. This situation was not the case all the time, as, in several 
instances, these ideas faced confrontation and resistance. Let us now turn to the domestic politics approach.

\section{Domestic Politics}

To understand decision-making strategies, one has to emphasize the importance of the domestic environment, the structure and activities of the state, and its institutions (Huelshoff 1994). Electoral cycles, domestic institutions and formations, opposition, and the public are just a few environmental factors that affect government decisions and their agendas. A domestic politics approach (inter alia Bulmer 1983; Huelshoff 1994; Ladrech 1994; Elster, Offe, and Preuß 1998; Verdun 2000; Heipertz and Verdun 2010; Dandashly 2015; Dandashly and Verdun 2016) informs us why a government chooses one policy over another and is best able to explain the specific timing of policies. Elites' preferences and choices affect the outcome of the policy. Scholars who adopt a domestic politics approach emphasize the importance of various domestic actors, as well as that of institutions at the national level, since they influence the positions of the governments (Dandashly 2015). The institutional, political, economic, and public readiness to adopt the euro is highly dependent on the elites' decisions and the existence of veto points, such as constitutional amendments that require agreement between various parties or presidential veto (Dandashly and Verdun 2016). Furthermore, the government's ideology and choices affect the central bank's policies and personnel, e.g., appointing euroskeptic members to the national central bank's monetary council. Thus, policies that favour euro adoption depend on an absence of veto points and the presence of a euro-enthusiastic government that can implement sound economic policies that would allow the country to meet the convergence criteria and adopt the euro.

These domestic factors do not operate in isolation from international economic factors. For instance, the EU could impose sanctions on member states if excessive deficits exist. ${ }^{4}$ The global financial crisis of 2008-2009 showed that international events may have an important influence on the calculation of the costs and benefits associated with being part of the euro area. However, these effects can differ based on the political and economic situation of the country.

\section{Political Economy}

There is a wealth of studies within the political economy literature that examines macroeconomic choices such as exchange rate regimes. This literature focuses on the degree of development, openness of the economy (share of trade to Gross Domestic Product [GDP]), and whether its business cycle is in sync with its major trading partners. Scholars such as Bernhard and Leblang (1999), Clark (2002), Hallerberg (2012), and Keefer and Stasavage (2002) focus on domestic factors to explain the choice of exchange rate regime. For instance, this literature suggests that a choice for any given exchange rate regime may be influenced by either "policy demanders" (interest groups and voters, e.g., Frieden 2002) or "policy suppliers" (political parties, legislatures

\footnotetext{
${ }^{4}$ As per the convergence criteria, EU member states are not allowed to breach the 3 percent reference value regarding their deficit except: (a) if the percentage of deficit to the GDP has been corrected and has come close to the reference value; and (b) if the violation of the deficit criteria is only temporary and due to exceptional circumstances. In case the percentage of public debt to GDP exceeds the 60 percent reference, then the debt of this country will be considered excessive (and in violation) unless the debt is improving and coming close to the reference value (Consolidated versions of the Treaty on European Union and the Treaty on the Functioning of the European Union [henceforth 'Consolidated Treaties'] Article 126: Paragraph 2) (Ex Article 104 of the Treaty Establishing the European Community [TEC]; see Official Journal of the European Union C321 2007 and Official Journal of the European Union C 83 2010).
} 
and bureaucracies, e.g., Bernhard, Broz, and Clark 2002). When examining the specific context of the EU, this literature often focuses on whether it is economically feasible for a country to give up the exchange rate instrument as an adjustment tool (Buiter 2000; De Grauwe and Schnable 2005; Lipschutz, Lane, and Mourmouras 2005; Schadler 2005; Eichengreen 2012).

\section{Hypotheses and Explanatory Variables}

From the aforementioned approaches, we deduce five possible explanations regarding euro adoption outcome and performance during the euro crisis:

First, the inferiority-superiority factor: The two parts of Czechoslovakia had different levels of development. Being less advanced and underdeveloped during communist rule and during the early 1990s created a sense of inferiority within Slovakia. Joining the euro while the Czech Republic did not would send a clear message to the Czechs and other EU countries that the supposedly last would be among the first newcomers to the euro area. As a partner in an important policy area, it was thought that being part of the euro area would give Slovakia a more influential role within the EU, and greater influence over Member States that were not part of the euro area. Therefore, Slovakia sought to adopt the euro to overcome an inferiority complex, while the Czech Republic did not share this concern. In fact, in the Czech case, the predominant feeling among elites was that the country was advanced enough to adopt policies based on national choices independent of what others might think it "ought" to do. H1: The feeling of inferiority pushed the Slovaks to adopt the euro faster than the Czechs.

Second, European identity: The sense of European identity might have pushed the newly established countries to join the EU and rush to adopt the euro. Following independence, the image of Slovakia, as held by non-Slovaks, was that it was not Europe-oriented. This was especially the case during the mid-1990s, when, under Prime Minister Mečiar, economic and political reforms slowed down while limitations to the freedoms and civil liberties increased. Thus, for Slovaks, it was important to join not only the EU, but also the euro area, and strengthen the status and influence of Slovakia at the EU level. EU membership and participation in the euro area gave Slovakia a stronger sense of European identity that was missing when it was still part of Czechoslovakia. Following the constructivist literature, one could examine whether euro adoption was part of a "return to Europe" strategy. In this case, the euro adoption strategy could be seen as creating a stronger sense of belonging to Europe. H2: Since the euro could be taken as a sense of European identity, the higher the need for a sense of belonging to Europe, the more probable that the country will adopt the euro.

Third, the symbolic factor: The sentimental feeling regarding losing the Slovak koruna (in favour of the euro) was not significant, since it was a new currency that existed only briefly after independence. There is some literature that suggests new currencies can be an expression of national identity, and therefore, countries that are in search of identity will not easily give up their currency. This literature further suggests that a young currency is not a fully anchored symbol or token of national identity (Gilbert and Helleiner 1999; Helleiner 2003). Following this logic, it was less of a problem to accept the euro in Slovakia because the Slovak koruna was not seen as a currency important enough to salvage. In contrast, the Czech Republic retained the koruna that had been circulating during Czechoslovakian times (October 1918 - January 1993). Thus, one could argue that the Czechs might be more attached to their national currency because it had a 
longer legacy. H3: The lower the attachment to one's own currency, the higher the probability that a country will join a currency union.

Fourth, euroskepticism: There are different degrees of euroskepticism and euro-enthusiasm within the Czech Republic and Slovakia. One might be able to trace the underlying reasons to the reform path: the political, economic, and institutional reforms undertaken by both countries might have led to different outcomes. The highly euroskeptic attitude within the Czech Republic - reflecting the former Czech president's euroskepticism for many years - could have affected the country's attitude towards the euro and caused the Czech Republic to stay outside the euro area, while Slovakia joined. The degree of euroskepticism in the Czech Republic and the lack of that same euroskepticism in Slovakia (post Mečiar) can explain their differing policies towards euro adoption. H4: The higher the degree of euroskepticism, the less likely it is that a country will adopt the euro.

Fifth, economic structure and trade relations: The economic structure and trade relations in Slovakia - especially the automobile industry - with Germany, accompanied by the perceived economic benefits, contributed to Slovakia's speedier euro adoption strategy. The Czech Republic did not have this same push from its euro area trading partners. The diversity of the Czech economy in comparison to the Slovak one (the latter being more dependent than the Czech Republic on the automobile industry) affected the clout of the automobile industry lobby in pushing for euro adoption. Therefore, Slovakia's trade relations with Germany and other partners, compared to that of the Czech Republic, put Slovakia in a position that was more favourable to euro adoption policies. H5: The urgency for euro adoption increases if the economic structure of the country is heavily dependent on one industry that, in turn, is in sync with the euro area.

These are the five explanations we are examining in this paper. Let us now turn to them one at a time.

\section{The Inferiority-Superiority Hypothesis - Does it hold?}

Even prior to Communism, before the creation of Czechoslovakia following the end of the First World War, the Czechs were the more dominant group of the two. The Slovaks had little influence on the form and functioning of the newly established state at that time (Goldman 1999, 3). The situation did not change with Communism, with which the economic inequality and gap between the advanced Czech and less privileged Slovak lands continued. Prior to the Velvet Divorce, the Czech part of former Czechoslovakia was more technologically and economically advanced and politically dominant. Following the separation, Slovakia inherited this underprivileged situation, yet managed to develop its economy, meet the convergence criteria, and adopt the euro. Can this commitment be explained by feelings of inferiority that pushed the Slovaks to outperform the Czech Republic's development and progress?

The road to the EU, and later to Economic and Monetary Union (EMU), was not smooth, and joining the EU was considered an historic moment for Slovakia. ${ }^{5}$ The steps that Slovakia took moved it ahead of other NMS - including the Czech Republic - that were considered more

\footnotetext{
${ }^{5}$ For hundreds of years, Slovakia had been a subordinate part of Hungary - and later Czechoslovakia. It did not have its own state except during the Second World War under the leadership of Jozef Tiso, who was a strong ally of Nazi Germany at the time.
} 
advanced and superior. With European integration, it moved forward and became among the pacesetters - "[it] makes Slovaks proud" (personal interview by the authors with an official from the National Bank of Slovakia, Bratislava, November 24, 2009).

Many politicians and the public considered adopting the euro in Slovakia a worthy goal (with 55 percent in 2006 and 2007 in favour of replacing their currency with the euro) (European Commission 2008). For many, adopting the euro was the next rational step after accession to further integration. The fear from the past in which Slovakia was left behind and did not have its own voice created large public and political support to adopt the euro (personal interview by the authors with a former official from the National Bank of Slovakia, Bratislava, November 23, 2009). Furthermore, for centuries, Slovakia lived on the periphery of international movements, including the Austro-Hungarian Monarchy (1867-1918), in which the Slovaks were a minority, and then in Czechoslovakia (1918-1993), where Slovakia was the smaller of the two nations. The country is now independent, but it did not start successfully from the point of view of the international community, which did not trust earlier governments that were not considered to be EU- or Western-oriented. Now, there is satisfaction in Slovakia that they are "among the first class in Europe"; have the same privileges as Germany, France, etc.; share the same currency as those countries; and were faster than others such as Czechs, Hungarians, and Poles to adopt the euro and thus join an area that contained the major EU countries (personal interview by the authors with an official from the National Bank of Slovakia, Bratislava, November 24, 2009). This view is also supported by that of the vice governor of the National Bank of Slovakia, Martin Burto, who on the record states that "it was a big psychological boost for this country that we were in the euro ahead of the Czechs and the Hungarians" (The New York Times July 3, 2009).

The psychological factor played an important role in pushing the Slovaks towards the euro and integrating further, as it gave them satisfaction that "the last can be first." They were pleased to be sitting alongside Germany, France, and others not only in the various EU meetings, but also in EMU meetings and meetings of the European Central Bank (ECB), having an equal vote in the process.

\section{European Identity and the Return to Europe}

While there is a high level of consensus within the academic literature that joining the EU marked a critical moment that brought NMS "back to Europe," from the point of view of the NMS, things are perceived differently. Perhaps surprisingly, many do not agree with the depiction of EU accession as relevant. In fact, when it comes to euro adoption, it is even less significant. For Slovakia, for example, during the interviews conducted by the authors, most interviewees signalled that the slogan "return to Europe" does not make much sense, as they have always been a part of Europe, so there is "nowhere to return to" (personal interviews by the authors with an official from the National Bank of Slovakia, Bratislava, November 23, 2009 and with officials from the Ministry of Finance, Bratislava, November 26, 2009). One official argued that maybe Slovakia was isolated from benefiting from Europe, but never left Europe. It was mainly a return institutionally back to Europe. The slogan "return to Europe" is rather a politically empty one, does not hold solid ground, and does not reflect the reality as "we always felt European" (personal interview by the authors with an official at the National Bank of Slovakia, November 24, 2009). Indeed, Slovaks are among the five member states that identify most with Europe. In 2009, 44 percent and in 2010, 45 percent 
of Slovaks surveyed reported they felt both Slovak and European (European Commission 2009, 2010a). In 2013, 76 percent of Slovaks indicated that they felt they were EU citizens (European Commission 2013a).

While Czech accession to the EU was a sign of returning to Europe, euro adoption did not have that same connotation, although some even added that "we always have been in Europe and never left" (personal interviews by the authors with officials from the Czech National Bank [CNB] and Ministry of Finance [MoF], Prague, June 2009). In an interview by Die Zeit (2003), Czech President Klaus answered a question regarding EU accession by saying that the Czech Republic did not have a choice, since the Czech Republic has been and will always be part of Europe. "Today, one cannot exist without EU membership in Europe. This is a marriage of reason, not of love. For a Central European country which is not located on an island or on the edge of Europe, it is simply impossible not to join the EU"' (Die Zeit April 17, 2003).

In history, Czechs have always been within "the German zone of influence," so interviewees stressed: "why pretend now other than that the EU accession marks a return to Europe?" The relevance of euro symbolism and that of the image of a "return to Europe" are not that significant (personal interview with an official from the CNB, Prague, June 2009). Czech interview partners pointed out that the Czech Republic (and even Slovakia) has always belonged to Europe, as it was at the crossroads between the East and the West, and Czechs disliked being labeled eastern Europeans, since it is a central European country (Brodský 2003-2004, 10; see also Holý 1996). For Czechs, the "return to Europe" slogan is mainly returning to a Europe that they always believed they were a part of and never felt distanced or separated from due to the shared culture and history (Brodský 2003-2004, 10). Interestingly, the Czechs felt that adopting the euro would cause some loss of national identity (70 percent agree; 29 percent disagree [European Commission 2014a, 8889], which is higher than in any other member state that had not yet adopted the euro).

In both the Czech and Slovak cases, the notion of a "European identity" and "return to Europe" were not that significant to euro adoption or EU accession in that the interviewees supported the argument that the perception among elites and the public at large in both countries is that they have always been a part of Europe, even during the Cold War.

\section{Symbolism and Attachment to the Currency}

According to various officials that were interviewed in Bratislava in the last week of November 2009, Slovaks did not really care about what the currency would look like, or what its name would be, since they argued that these matters do not affect their wealth. Interview partners argued that Slovaks did not connect much with their national currency until late 2009; they claim not to identify with it. Rather, in the eyes of various officials, Slovaks are perceived to care more about how much money they make and how much they can buy with it, rather than the symbolism around retaining a national Slovak currency. However, citizens who travel more would have a stronger feeling of European belonging by having the euro. Yet, this group is relatively small in comparison to the number of Slovaks who have never left their country or who have only visited neighbouring countries such as the Czech Republic or Hungary. The local currency does not really affect the way Slovaks feel about being European (personal interview by the authors with an official from the National Bank of Slovakia, November 23, 2009). As mentioned above, Eurobarometer data 
supports this argument. The percentage change of citizens who feel more European because of the euro in Slovakia was 26 percent in 2010 and 22 percent in 2014, compared to 73 and 75 percent (in 2010 and 2014 respectively) who felt no change at all (European Commission 2010b, 2014b). Moreover, with the euro crisis and the economic difficulties faced by Slovakia, the nationalist sentiments are increasing at the expense of the European identity.

Similar to Slovaks, most Czechs tend to think about euro adoption in economic terms. Close to ninety percent of the population thought about the costs and benefits of adopting the euro with respect to their salaries, pensions, and personal accounts as having priority over other issues. In other words, how much individuals can purchase with their salaries takes precedence over other concerns. One important difference with Slovakia is that, in the Czech Republic, around 67 and 61 percent of the population, in 2009 and 2010 respectively, thought that using the euro would make people feel more European (European Commission 2009, 2010a). However this percentage decreased in recent years to 30 percent and 34 percent in 2013 and 2014 respectively (European Commission 2013b, 2014a).

At the same time, Czech citizens did not consider euro adoption a significant issue; it was not seen as a priority or cause of stability (personal interviews by the authors with officials from the MoF, Prague, June 2009). Compared to other NMS, the Czech Republic is the most euroskeptic country of all those that joined the EU in the 2000s. Eurobarometer data for 2009 shows that 54 percent of the population was dissatisfied with the fact that the euro would replace their currency at some point, while only 37 percent was content with this prospect. With the euro crisis, the percentage of Czech citizens against adopting the euro reached 77 percent in 2014 (European Commission 2014a). Czechs "like their currency," which has been strong and dates back to the 1920s (personal interview by the authors with an official from the CNB, Prague, June 2009). Even during Communism, Czechoslovakia had a stable, strong currency in comparison with other Communist countries. Czechs are "very pragmatic. They have a preference for a stable currency. But as such, the euro has nothing positive. Maybe they use it for travelling, but [it would] not really [be] associated with the issue of being more European or closer to the EU, if they had the euro as their currency" (personal interview by the authors with an official from the CNB, Prague, June 2009).

Thus, the symbolic effect of the euro is absent in the Czech case (personal interview by the authors with officials at CNB and MoF, Prague, June 2009). The Czechs are proud of the koruna and Czech sovereignty (personal interview by the authors with key informant from Euro Team, Prague, June 2009). The Czech Republic has had a strong koruna, and given the problems of the euro (weakened after its launch) and subsequently the sovereign debt crisis, the value of the national symbol of the Czech koruna has increased. The flipside of the coin is that it lowered local trust in the EU institutions to 37 percent in 2012 and increased fears that the crisis would negatively affect the Czech Republic's automobile industry (EUobserver January 25, 2013). This situation makes it harder for people to accept another currency and has strengthened the euroskeptic view that was fostered by then-Czech President Václav Klaus.

\section{Institutional, Political, and Economic Reforms}

Most of the literature dealing with Europeanization in the NMS focuses on institutional effects. Our focus is on the influence of the central bank and some important reforms taken by consecutive 
Czech governments. The continuous Europeanization process and entry of NMS countries to the EU affected the existing parties' ideology, party system, and domestic politics (see Baun, Dürr, Marek, and Šaradin 2006). This process also served to create a suitable environment for adopting the German model of independent central banks. Many EU and international financial institutions, such as the Deutsche Bundesbank, Bank of England, International Monetary Fund (IMF), World Bank, Federal Reserves, and the Bank for International Settlements (BIS), implemented many programs (such as Phare) to help NMS countries adopt the necessary political, economic, and institutional reforms to join the EU and later adopt the euro. These western institutions provided the necessary training to a large number of personnel in the central banks, including the CNB and the National Bank of Slovakia (NBS), leading to a social learning process and transfer of "ideologies, practices, and internal organizational frameworks" (Johnson 2003, 3; see also Johnson 2006, 2008). While EU support to the Central and East European Countries (CEECs) was significant prior to the accession period, the European Commission did not offer significant political, financial, and economic support for countries seeking to meet the convergence criteria. However, once a member state met the criteria, the Commission provided know-how, twinning, and best practices to assist in the transition period (personal interview by the authors with an official of the Ministry of Finance, Czech Republic, Prague, June 2009).

\section{i. $\quad$ The Czech Case}

In the case of the Czech Republic, the EU and other international institutions provided the necessary training and guidance, technical assistance, and development to move the Czech institutions and their employees away from the communist era. This support enabled them to play an important role in the country's economic liberalization process. Experts from EU member states were also involved in the training process in order to "familiarize bureaucrats in the Czech Republic [...] with EU policy compliance," which resulted in the extensive diffusion "of EU practices in the Czech financial and banking sector" (Vliegenthart and Horn 2007, 148). Among the reforms implemented was the creation of an independent central bank in 1993. This development was unpopular amongst politicians and led to strained relations between the government and the CNB - particularly between 1997 and 2005, when the CNB board and Czech government had different views regarding macroeconomic policies and euro adoption (see Dandashly and Verdun 2016).

The transfer of ideas, technical assistance, and socialization created a culture of privatization, which aimed to transform the economy into a properly functioning market economy. However, privatization processes were not accompanied by "a regulatory framework to keep these development[s] in check" (Vliegenthart and Horn 2007, 142). The absence of this critical institutional reform is worth noting. Consequently, corruption was still present within the banking system, which did not follow suit regarding privatization, and ties between government officials and state-controlled banks were not severed. All these developments led to an unstable currency, economic recession, and market failure in 1997. This situation pushed the Organization of Economic Cooperation and Development (OECD) to state that one of the building blocks of good governance and economic performance in the Czech Republic is the privatization of the stateowned banks (OECD 2000, 79). Moreover, there were a variety of EU programs - such as the Phare program - that provided institutions and administrations in the Czech Republic and Poland, such as the MoF and CNB, with technical assistance. EU programming also sought to help move 
the Czech Republic to a new market economy similar to its fellow western EU countries, and to implement the EU acquis communautaire (ibid., 146-148).

Another important factor was the democratic system that emerged after the fall of Communism in 1989. The Czech Republic's new democratic system of governance gave the president significant powers. The two term presidencies of Václav Klaus (2003-2013) further strengthened the role of the president. In the Czech case, the role of euroskeptic President Klaus is of particular importance to the extent that "it is not too much of an exaggeration to claim that ideological[ly-]based politics in the Czech Republic is largely shaped by politicians' and voters' reactions to the Klausite vision" (Haughton 2009, 1383). His euroskepticism is derived from 'an 'Anglo-Saxon' neo-liberal economic critique of the EU as an inefficient, over-regulated and 'socialist' structure dominated by self-seeking bureaucratic elites with far-reaching political ambitions [...] and a 'national' critique of the EU as a threat to Czech national sovereignty and identity" (Hanley 2007, 191; see also Haughton 2009). During his presidency, Klaus appointed officials to the central bank's monetary board who shared his euroskeptic views, and thus did not favour a speedy euro adoption process. ${ }^{6}$ Klaus argued that the main economic benefits of European integration were trade liberalization and the flow of Foreign Direct Investment (FDI). According to Klaus, the costs of adopting the euro outweighed the benefits, and "further economic or non-economic unification will be close to zero, if not negative" (Klaus 2003). As a trained economist, he also, "saw the problems that a single currency would bring even before the euro was formally launched... [T] he euro would create serious problems for the countries that accepted the single currency in place of their own national currencies" (Feldstein 2011). Klaus was widely critical of the Maastricht Treaty, the euro project, and its consequences. To him, the Maastricht Treaty represented a "turning point at which European integration turned away from its original liberalizing mission and took on an unacceptable federalist course" (Hanley 2007, 210).

Despite the departure of Klaus in 2013, euroskepticism may continue within the Czech Republic for some time to come. Within the Czech Republic, it seems that euroskepticism may have been further fuelled by the euro crisis. It provides support for the position held by some that economic instability within the EU is to blame for economic troubles that the country has recently faced. This perspective has placed further emphasis on national sovereignty - especially in the case of smaller EU member states such as the Czech Republic (EUobserver January 25, 2013). Despite the lack of public support for the issue, the current Czech President, Miloš Zeman, is more proeuro adoption. However, given that the Czech central bank governor is more cautious, and with elections coming up in October 2017, the current government is not on a path to speedy euro adoption. The decision as to when to adopt the euro has been left to the next government.

\section{ii. The Slovak Case}

The early and mid-1990s was a difficult period in the history of Slovakia. Following the Velvet Divorce, Slovakia was in an underprivileged economic situation resulting from previous decades of communist rule that had favoured Czech lands. Slovakia's economy was developing at a much slower pace than the other NMS. In addition, the troubled political situation in the mid-1990s led to the exclusion of Slovakia from the first round of EU accession negotiations. However, economic

\footnotetext{
${ }^{6}$ The current board members are either against the euro project or are euroskeptics (personal interviews by the authors with officials from the CNB, Prague, June 2009).
} 
reform started in the early 1990s, and the political situation changed in the second half of the 1990s with the end of Vladimír Mečiar's rule. ${ }^{7}$

Since we underlined Mečiar's role in creating a political situation that delayed EU accession negotiations, it is important to highlight Slovakia's governmental and presidential powers, as they played a key role in the county's EU accession and euro adoption. In comparison to the role of the presidency in the Czech Republic, the Slovak presidency is weaker and more ceremonial. The strong position in the Czech Republic is not only because of constitutional powers given to the president, but also due to the personality of former president Klaus (2003-2013). The weaker presidency in Slovakia (compared with the Czech Republic), along with a strong independent central bank that has been pro euro, greatly influenced the euro adoption strategy. Although the Slovakian president appoints and dismisses the governor and the vice governor, the appointment and dismissal of the monetary board is the duty of the government. These provisions strengthen the independence of the central bank in Slovakia, as opposed to the Czech Republic, where the president has more say in the appointment process.

Following the Mečiar years (1990-1998), the Slovak government had consistently focused on EU accession and euro adoption with 2008-2009 as the target. In 2003, the NBS and the Ministry of Finance published a report on euro adoption, Strategy of Adopting the Euro in SR. This report was followed by two other joint reports: Specification of Euro Adoption Strategy and National Euro Changeover Plan for the Slovak Republic (NBS and Ministry of Finance 2003, 2004, 2005). In 2005, the government approved the euro adoption plan, which was implemented by the subsequent government following the 2006 elections that resulted in the Direction-Social Democracy Party (Smer-sociálna demokracia, Smer-SD) winning 29.14 percent of the vote, while the major party in the former ruling coalition Slovak Democratic and Christian Union - Democratic Party (Slovenská demokratická a krest'anská únia - Demokratická strana, SDKÚ-DS) got only 18.35 percent (Statistical Office of the Slovak Republic 2006). It is remarkable that all elites were in favour of euro adoption. The coalition government, at that time led by Smer-SD leader Robert Fico, did not change the euro adoption target date, and proceeded with the needed reforms to meet the convergence criteria. Around the same time, there were important in-depth analyses of the effects of the euro on various sectors in Slovakia, such as on the economy, population, and business sector. These studies were conducted by the NBS and confirmed that, for Slovakia, the benefits of euro adoption would outweigh the costs (NBS 2006; Árendás 2006). The NBS believed that Slovakia needed to join the euro area to fully benefit from monetary integration (Pechova 2012, 8).

Consecutive national governments shared the NBS's view that euro adoption would be important for the development of the Slovak economy. Slovakia's position was to implement policies in favour of meeting the convergence criteria, since in the words of the NBS, it was considered "inevitable, irrespective of accession. Effective public finance, education and health care systems,

\footnotetext{
${ }^{7}$ Mečiar - who was the prime minister for three terms (June 27, 1990 - April 22, 1991; June 24, 1992 - March 15, 1994; and December 13, 1994 - October 30 1998) and the acting president for two periods (January 1, 1993 - March 2, 1993 and March 2, 1998 - October 30,1998) - detached Slovakia from its neighbours economically and politically, and delayed reforms (see Allam 2006, 191). The EU and the West criticized Mečiar for turning Slovakia into an autocratic regime.
} 
as well as a flexible labour market are essential for the problem-free operation of any economy" (NBS 2003, 9). Both the government and the NBS agreed that all of the required reforms to adopt the euro were crucial for greater economic development and a more stable and advanced economy, and also to attract foreign investors (NBS 2003, 10).

\section{Economic Structure and Trade Relations}

According to some officials at the Czech National Bank, despite the argument that, in the long term, euro adoption has significant macroeconomic benefits, by meeting the convergence criteria, countries would in principle be more disciplined (personal interviews by the authors with officials from CNB, Prague, June 2009). ${ }^{8}$ According to Czech officials, the main benefit of the macroeconomic outcomes would be price stability. Some of them argue that, if price stability is the main benefit, and if the Czech Republic has already achieved this goal while not a euro member, then what is the point of joining the euro area? (Hurník, Tůma and Vávra 2010, 194).

Prior to its accession to the euro area, Slovakia managed to meet the convergence criteria, while the Czech Republic was very close to meeting them. In 2006, for example, it met the criteria on inflation, deficit, interest rate, and debt (see tables 1 and 2).

Table 1: Slovakia Macroeconomic Data

\begin{tabular}{|c|c|c|c|c|c|c|c|c|c|c|c|c|c|c|}
\hline Slovakia & 2001 & 2002 & 2003 & 2004 & 2005 & 2006 & 2007 & 2008 & 2009 & 2010 & 2011 & 2012 & 2013 & 2014 \\
\hline Inflation & 7.2 & 3.5 & 8.4 & 7.5 & 2.8 & 4.3 & 1.9 & 3.9 & 0.9 & 0.7 & 4.1 & 3.7 & 1.5 & -0.1 \\
\hline $\begin{array}{l}\text { Inflation } \\
\text { Ref. }\end{array}$ & 3.1 & 2.6 & 2.7 & 2.2 & 2.5 & 2.9 & 2.8 & 4.1 & 3.9 & 3.9 & 5.8 & 3.1 & 2.7 & 1.7 \\
\hline Interest & 8.04 & 6.94 & 4.99 & 5.03 & 3.52 & 4.41 & 4.49 & 4.72 & 4.71 & 3.87 & 4.45 & 4.55 & 3.19 & 2.07 \\
\hline $\begin{array}{l}\text { Interest } \\
\text { Ref. }\end{array}$ & 6.92 & 6.85 & 6.12 & 6.28 & 5.37 & 6.24 & 6.4 & 6.6 & 5.9 & 5.2 & 3.1 & 5.8 & 5.5 & 6.2 \\
\hline $\begin{array}{l}\text { Debt (\% } \\
\text { of GDP) }\end{array}$ & 48.9 & 43.4 & 41.5 & 40.6 & 33.8 & 30.7 & 29.8 & 28.2 & 36.0 & 40.9 & 43.4 & 52.1 & 54.6 & 53.6 \\
\hline Debt Ref. & 60.0 & 60.0 & 60.0 & 60.0 & 60.0 & 60.0 & 60.0 & 60.0 & 60.0 & 60.0 & 60.0 & 60.0 & 60 & 60 \\
\hline $\begin{array}{l}\text { Deficit (\% } \\
\text { of GDP) }\end{array}$ & 6.4 & 8.1 & 2.7 & 2.3 & 2.9 & 3.6 & 1.9 & 2.4 & 7.9 & 7.5 & 4.1 & 4.2 & 2.6 & 2.9 \\
\hline $\begin{array}{l}\text { Deficit } \\
\text { Ref. }\end{array}$ & 3.0 & 3.0 & 3.0 & 3.0 & 3.0 & 3.0 & 3.0 & 3.0 & 3.0 & 3.0 & 3.0 & 3.0 & 3.0 & 3.0 \\
\hline GDP & 3.5 & 4.6 & 5.4 & 5.2 & 6.5 & 8.3 & 10.7 & 5.4 & -5.3 & 4.8 & 2.7 & 1.6 & 1.4 & 2.4 \\
\hline
\end{tabular}

Source: Eurostat 2015

\footnotetext{
${ }^{8}$ Some experts and scholars debated this statement, since euro members violated the criteria even before the financial and the euro crises (see Heipertz and Verdun 2010 on the breach of the rules of the Stability and Growth Pact [SGP]).
} 
Table 2: Czech Republic Macroeconomic Data

\begin{tabular}{|c|c|c|c|c|c|c|c|c|c|c|c|c|c|c|}
\hline $\begin{array}{l}\text { Czech } \\
\text { Republic }\end{array}$ & 2001 & 2002 & 2003 & 2004 & 2005 & 2006 & 2007 & 2008 & 2009 & 2010 & 2011 & 2012 & 2013 & 2014 \\
\hline Inflation & 4.5 & 1.4 & -0.1 & 2.6 & 1.6 & 2.1 & 3.0 & 6.3 & 0.6 & 1.2 & 2.1 & 3.5 & 1.4 & 0.4 \\
\hline $\begin{array}{l}\text { Inflation } \\
\text { Ref. }\end{array}$ & 3.1 & 2.6 & 2.7 & 2.2 & 2.5 & 2.9 & 2.8 & 4.1 & 3.9 & 3.9 & 5.8 & 3.1 & 2.7 & 1.7 \\
\hline Interest & 6.31 & 4.88 & 4.12 & 4.82 & 3.54 & 3.80 & 4.30 & 4.63 & 4.84 & 3.88 & 3.71 & 2.78 & 2.11 & 1.58 \\
\hline $\begin{array}{l}\text { Interest } \\
\text { Ref. }\end{array}$ & 6.92 & 6.85 & 6.12 & 6.28 & 5.37 & 6.24 & 6.4 & 6.6 & 5.9 & 5.2 & 3.1 & 5.8 & 5.5 & 6.2 \\
\hline $\begin{array}{l}\text { Debt (\% } \\
\text { of GDP) }\end{array}$ & 23.9 & 27.1 & 28.1 & 28.5 & 28.0 & 27.9 & 27.8 & 28.7 & 34.1 & 38.2 & 39.9 & 44.6 & 45.0 & 42.6 \\
\hline Debt Ref. & 60.0 & 60.0 & 60.0 & 60.0 & 60.0 & 60.0 & 60.0 & 60.0 & 60.0 & 60.0 & 60.0 & 60.0 & 60.0 & 60.0 \\
\hline $\begin{array}{l}\text { Deficit (\% } \\
\text { of GDP) }\end{array}$ & 5.3 & 6.3 & 6.4 & 2.7 & 3.1 & 2.3 & 0.7 & 2.1 & 5.5 & 4.4 & 2.7 & 3.9 & 1.2 & 2.0 \\
\hline $\begin{array}{l}\text { Deficit } \\
\text { Ref. }\end{array}$ & 3.0 & 3.0 & 3.0 & 3.0 & 3.0 & 3.0 & 3.0 & 3.0 & 3.0 & 3.0 & 3.0 & 3.0 & 3.0 & 3.0 \\
\hline GDP & 3.1 & 2.1 & 3.6 & 4.9 & 6.4 & 6.9 & 5.5 & 2.7 & -4.8 & 2.3 & 2.0 & -0.8 & -0.7 & 2.0 \\
\hline
\end{tabular}

Source: Eurostat 2015

Figure 1: GDP Growth in Percent

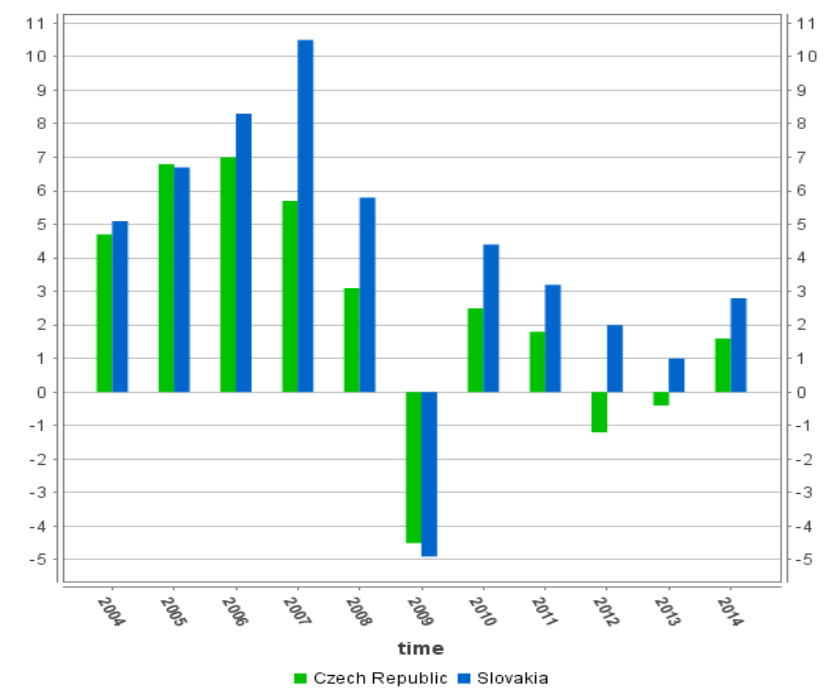

Source: Eurostat 2015 
Since 2004, GDP growth of the Slovak economy has been ahead of that of the Czech Republic, with the exception of 2005 (see figure 1). The automobile industry in Slovakia accounts for "41 percent of overall industrial output" (EUbusiness April 17, 2013).

In the late 1990s and early 2000s, the FDI flow into Slovakia increased considerably. This was mainly due to the automobile industry, which was facilitated by an active foreign business lobby. These lobbyists (e.g., German company Volkswagen) pushed hard for euro adoption, since their economic benefit would be significant (Haughton 2010, 12; personal interviews by the authors with various Slovak officials, Bratislava, November 2009). The increase in automobile production has helped create thousands of jobs, even after the economic problems of 2009. The economic growth has benefited significantly from the Volkswagen (VW) plant in Bratislava, Peugeot/Citroen in Trnave, and Kia in Žiline, and diversified international export destinations, such as South America, China, and Brazil (Správy April 1, 2013). Thus, the market for Slovak automobiles is not heavily dependent on the demand from EU countries only. Given that it is one of the largest employers in the country, with a significant share in the Slovak industry (41 percent in 2012; see figure 2), the automobile industry lobby is one of the most influential in Slovakia.

Figure 2: Share of Automotive Industry in Slovak Industry

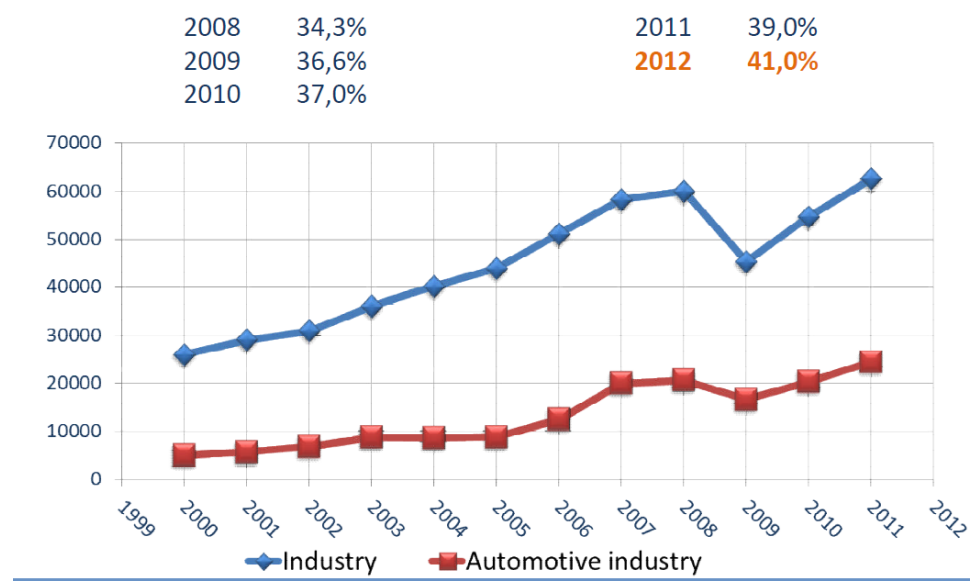

Source: Holeček (2013)

The Czech Republic also relies heavily on the automobile industry; however, its economy is more diversified. The main foundations of Czech industry are engineering, mining, chemistry, and foodstuffs, and to a lesser extent, the energy industry (The Czech Republic, Ministry of Foreign Affairs, 2013). The automobile industry accounts for around 20.1 percent of the total Czech industry (see figure 3). This share made the automobile lobby one important player among many, which prevented it from playing a significant role in pushing for fast euro adoption. 
Figure 3: Share of Automotive Industry in Czech Industry

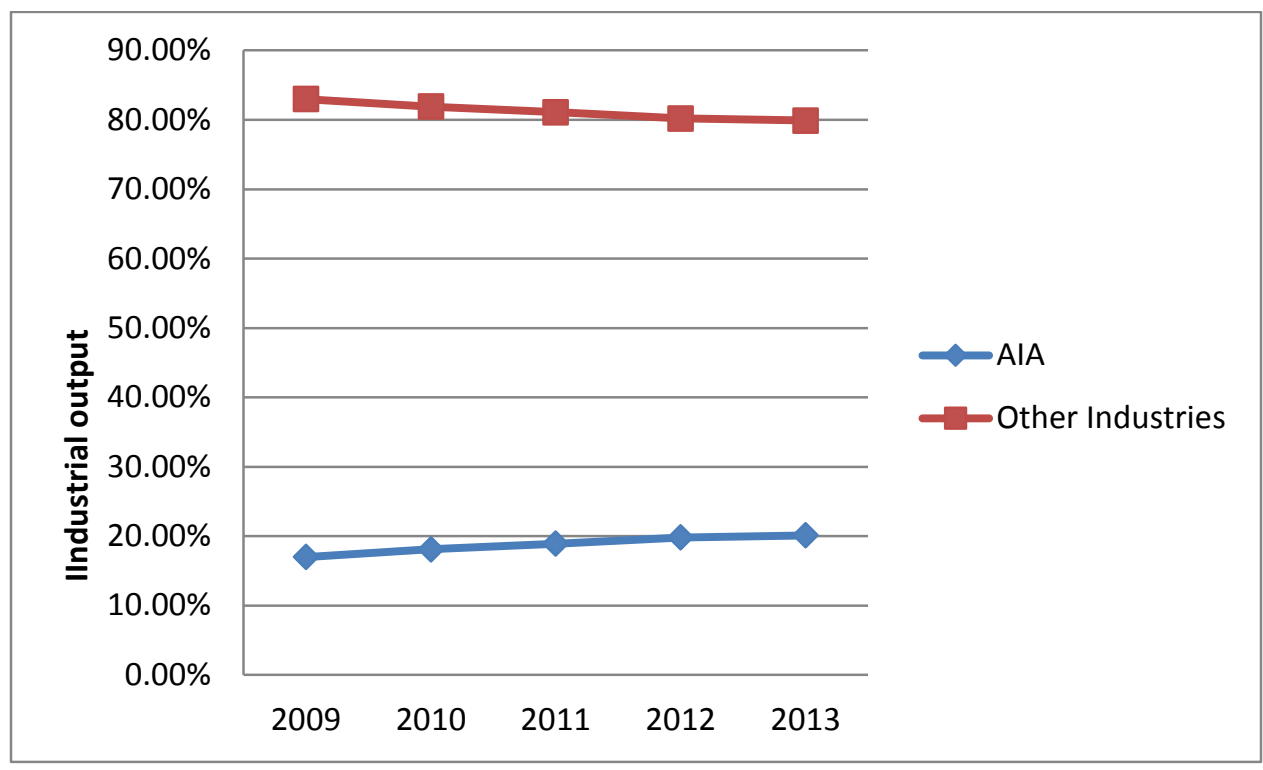

Source: Data from the Automotive Industry Association (2014)

\section{Financial and Sovereign Debt Crises}

Prior to the ECOFIN Council decision on July 8, 2008 to allow Slovakia to adopt the euro as of January 1, 2009, the economic development of both countries had similar characteristics. Both economies are export-oriented. The GDP share of Czech exports was 62.3-77.2 percent from 20052013, and that of Slovakia reached 72.1-93.0 percent of GDP in 2005-2013 (World Bank Data 2015). Both economies exhibited a considerable level of nominal convergence before Slovakia's entry into the euro area was confirmed (Jevčák 2011, 2). Up until the outbreak of the crisis in 2008, despite the differences in inflation rates (1.8 percent in Slovakia, compared with 3 percent in the Czech Republic in 2007, and GDP that reached 5.5 in the Czech Republic, compared with 10.7 in Slovakia in 2007), interest rates in the Czech Republic and Slovakia were very close (around 4.3 and 4.5 percent respectively). The debt in both countries was less than 30 percent of GDP, and the deficit in both countries was within the reference value (see tables 1 and 2). The outbreak of the crisis and the Slovak adoption of the euro raises the question of whether the exchange rate regime adopted by both countries influenced their economic performance during the crisis.

Both the financial crisis and the sovereign debt crisis affected the Czech Republic negatively, though not as badly as other countries (such as Hungary). The Czech industry - especially the automobile industry - suffered significantly. Most countries that the Czech Republic trades with were influenced negatively by the crisis and entered into recession. The negative effect of the crisis on the Czech Republic's main trading partners ${ }^{9}$ had its implications on the Czech economy (see

\footnotetext{
${ }^{9}$ The countries to which the Czech Republic exported the most in 2013 were: Germany (\$44.3Billion [B]), Slovakia (\$11.5B), Poland (\$7.9B), France (\$7.76B), and the United Kingdom (\$7.46B).

The countries from which the Czech Republic imported the most were: Germany $(\$ 37.1 \mathrm{~B})$, China (\$15B), Poland (\$10.7B), Slovakia (\$8.68B), and Russia (\$7.4B). Source: http://atlas.media.mit.edu/en/profile/country/cze/
} 
table 2). GDP growth declined and the Czech Republic performance on the convergence criteria diverged from the levels needed to be ready for euro adoption, thereby giving the euroskeptic group a good argument against a fast euro adoption.

Slovakia was not immune to effects of the financial and sovereign debt crises. After having one of the highest GDP growth rates in 2006 and 2007 (8.3 and 10.7 percent respectively), the GDP declined significantly in the crisis years (see table 1 and figure 1). However, with respect to GDP, it still performed much better than the Czech Republic during the crisis, except during 2009 (see Figure 1). Moreover, the macroeconomic data also suffered from the crisis, with deficit and debt increasing. In comparison to the Czech Republic, the deficit and inflation were higher in Slovakia, and the country's unemployment rate also increased significantly. ${ }^{10}$

\section{Figure 4: Unemployment Rate}

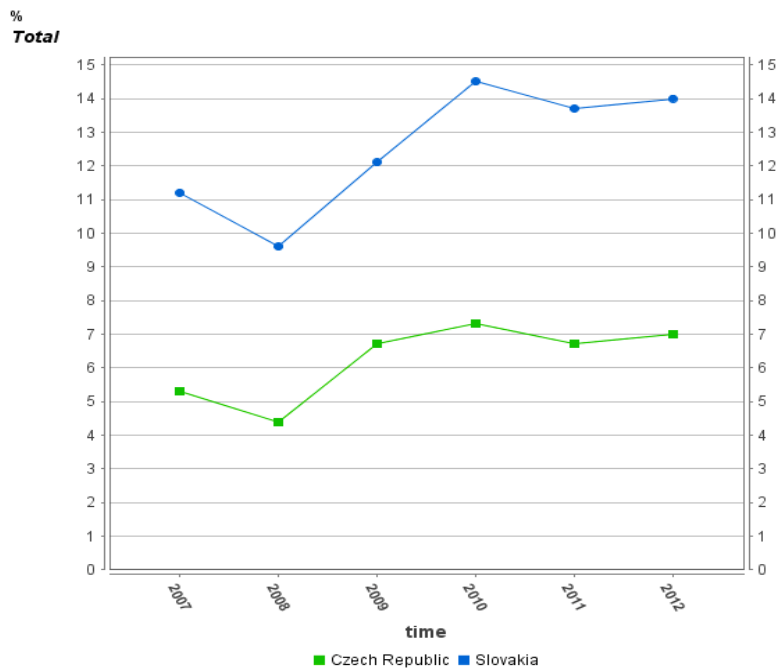

Source: Eurostat 2015

According to the OECD (2009), the automotive industry was a blessing prior to the crisis, and is now (post-crisis) a curse, greatly contributing to the deteriorating economic situation. The global recession had a negative effect on the automotive industry in Slovakia, which employs a large percentage of the population. This situation is strongly related to the economic slow-down with the major trading partners, especially Germany, and the decrease in the demand for Slovak products. Both the Czech Republic and Slovakia suffered from a decline in their exports (as a percentage of GDP), especially in 2009 before recovery started in both countries (figure 5).

\footnotetext{
${ }^{10}$ The unemployment rate in Slovakia was much higher, even prior to the crisis (see Figure 4).
} 


\section{Figure 5: Exports of Goods and Services (\% of GDP)}

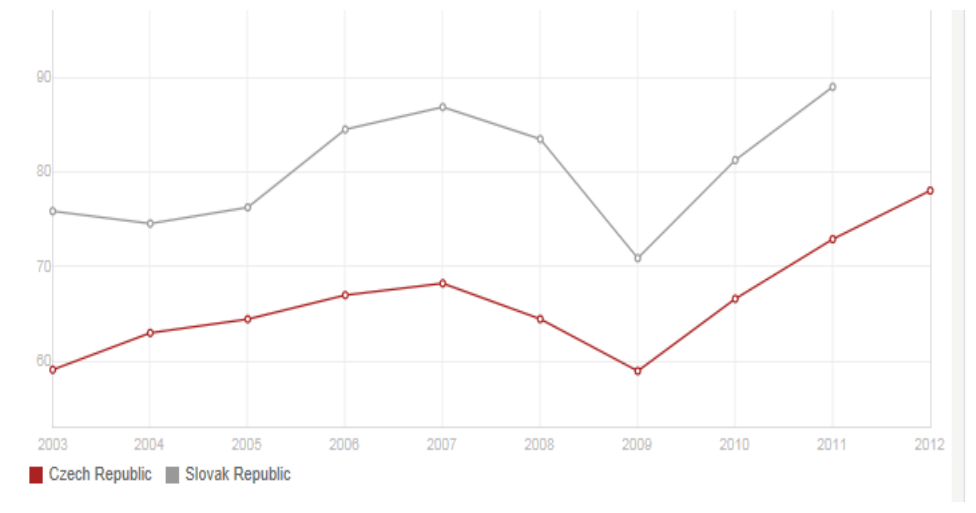

Source: World Bank Data 2015

The relatively better performance of the Czech economy during the crisis with respect to employment, deficit, and "real exports, as well as manufacturing production," means that the "overall financial market situation remained more stable" (Jevčák 2011, 10). ${ }^{11}$ This better performance at the financial level was facilitated by the ECB intervention that "was more aggressive and effective in easing monetary conditions than the CNB" (ibid., 6). Thus, it did not really matter much what type of exchange rate those countries had during the crisis, as both economies performed somewhat similarly. Being part of the euro, thus lacking the flexible exchange rate, did not really damage the Slovak export sector, "while euro-area membership provided an effective shield for its financial markets during the recent crisis period" (ibid., 10). Furthermore, in regards to inflation, despite its increase in 2011 to 4.1 percent in Slovakia, it managed to go down again (lower in comparison to other countries, including the Czech Republic) (see tables 1 and 2).

Politically, the Czech government used the financial crisis, and subsequently the sovereign debt crisis, as a tool to support its position of delaying euro adoption. Before the crisis, the Czech Republic was only missing two of the convergence criteria (inflation rate and the exchange rate). In the aftermath of the 2008/2009 financial crisis, the economic situation worsened. The entire effort of all groups (the CNB and both the government and opposition) was to deal with the fallout of the crisis - euro accession was not a priority. Another matter has been the reform of the pension system and health care policies. Without reform, there would be, in due course, more pressure on the public debt and deficit. The crisis supported the long-standing position of ODS and the government that the Czech Republic would join when it was "in its best interest." The population generally supports this position. In January 2011, Medea Research (based in the Czech Republic) conducted an opinion poll that showed that 77 percent of Czech citizens were against euro adoption, compared with 15 percent who were in favour. The poll also showed that 57 percent "strongly disagree with joining the euro zone" (Prague Daily Monitor March 4, 2011). The public is more skeptical regarding the entire European integration process in general, and the euro in

\footnotetext{
${ }^{11}$ http://ec.europa.eu/economy finance/publications/economic briefs/2011/pdf/ecobrief_14_may2011_en.pdf
} 
particular. These questions were not posed in the most recent Eurobarometer on euro adoption in recently-acceded member states (European Commission 2014a). In Slovakia, despite all of the problems the euro area currently faces, support for the euro remains among the highest. When asked by a Eurobarometer team if they are for or against a "European economic and monetary union with one single currency, the euro," 80 percent of Slovaks were in favour (European Commission 2012, T69).

\section{Conclusion}

We set out to analyze why Slovakia sought to adopt the euro while the Czech Republic did not. Let us revisit the arguments that we investigated to find out to what extent different variables can explain the different outcome in both countries.

The first explanation focused on the hypothesis that Slovakia sought to adopt the euro to overcome an inferiority complex. The Czech Republic did not have this same issue. This paper showed that, on the whole, prior to euro adoption, Slovaks did indeed feel inferior to Czechs. Some of the interviewees responded that the euro adoption strategy was inspired by seeking to overcome the inferiority complex, the "little brother syndrome." However, not all interviewees agreed that this factor was present, let alone decisive.

The second possible explanation - that the euro adoption strategy was used to create a stronger sense of belonging to Europe-was refuted in both countries. The interviewees in both countries did not agree that the adoption of the euro was to signal a return to Europe. Thus, the "return to Europe" argument was not seen to be important in either country.

The third explanation focused on the different korunas in both countries. It was hypothesized that it might not be a problem to accept the euro in Slovakia because the Slovak koruna was not seen as a currency important enough to salvage. Indeed, in the case of Slovakia, citizens did not seem to have a strong preference for which currency was used. They cared more about economic wealth than about whether the national currency was the euro or the koruna. In the Czech Republic, the situation could have been a non-issue, as well. However, compared with the Slovak case, the Czechs were prouder of the koruna and its function of symbolizing Czech sovereignty. The Czechs also worried more than the Slovaks that by adopting the euro, one might give up some of one's national identity.

The fourth argument, that the degree of euroskepticism in the Czech Republic and the lack of that same euroskepticism in Slovakia over the same time period could explain their differing policies towards euro adoption, was supported by the analysis. Euroskepticism in the Czech Republic gained further recognition and strength thanks to the consecutive election of former president Václav Klaus in 2003 and 2008 respectively. Klaus's euroskepticism has been very important on the Czech political scene. As president, not only did he influence public opinion and policies, but he also appointed euroskeptic officials to the central bank's monetary board. In Slovakia, during the early years following the Velvet Divorce, the figure of Vladimír Mečiar had a similar dampening effect on European integration. However, once Mečiar left office in the late 1990s, Slovakia went into "catch-up mode" and managed to join the EU in 2004. Since then, there has not been a comparatively strong euroskeptic political persona in power in Slovakia. 
The fifth explanation concerning economic structure and trade relations showed that Slovakia's relations with Germany and other partners, compared to those of the Czech Republic, put Slovakia in a position that was more favourable to euro adoption policies. In interviews, we found support for this hypothesis in the case of Slovakia. There were various references to the automobile sector and FDI from Germany to Slovakia. The same strong connection is absent in the Czech Republic. Although this perception came out of the interviews, it is not certain whether the situation in the Czech Republic is very much different on this matter, even if a little less determined by the automobile industry. Yet, perhaps other factors are more important to determine the Czech stance on euro adoption (for instance, euroskepticism of the president).

Reviewing the five explanations, we find that, to understand the different outcomes in the Czech Republic and Slovakia, we need a combination of these five explanations. Yet, based on an assessment of the five explanations, we conclude that the one based on domestic politics was the most influential. For example, the dominance of the euroskeptic president in the Czech Republic was an important reason for the Czech Republic's lack of interest in a fast path to euro adoption. The appointment of euroskeptic members to the CNB monetary board during the two terms of president Klaus reinforced the government's slow euro adoption policies. In the Slovak case, it seems that the absence of a euroskeptic leader, in addition to the fact that it had a weaker starting point, was crucially important. With Klaus having left his position, euroskepticism seems to prevail in Czech society, at least for the time being. The points that stand out are that Slovakia wanted to profile itself, did not feel a need to demonstrate national identity, and wanted to adopt the euro before the Czech Republic as a way to overcome its inferiority complex. The lobby from the automobile industry also played a role, albeit a minor one. However, if a few factors had been different in either country, the euro adoption strategy might have been different. The specific existence of various factors meant that one country rushed to euro adoption (Slovakia), whereas the other country (Czech Republic) was very reluctant. 


\section{REFERENCES}

Allam, M. S. 2006. Adopting the Euro in Central Europe: Cross-national Variations in the Strategies of the Czech Republic, Hungary, Poland and Slovakia. Unpublished Ph.D. dissertation, London UK: London School of Economics.

Árendáš, Marek. 2006. "An Assessment of the Potential Effects of the Euro Changeover on Slovakia's Business Sector," National Bank of Slovakia BIATEC XIV, 9/2006.

Automotive Industry Association. 2014. Czech Automotive Industry - Basic facts and Figures Data for 2013 year. Accessed May 1, 2014. http://www.autosap.cz/default2e.asp?page $=\{92 \mathrm{C} 42442-92 \mathrm{CB}-4197-9 \mathrm{EE} 0-9839 \mathrm{~A} 3 \mathrm{E} 65150$

Baun, Michael, Jakub Dürr, Dan Marek, and Pavel Šaradin. 2006. "The Europeanization of Czech Politics: The Political Parties and the EU Referendum," JCMS: Journal of Common Market Studies 44 (2): 249-280.

Brodský, Jiří. .2003-3004. “Czech Identity and Returning to Europe,” Sien Quarterly 1-2: 9-22.

Bulmer, Simon J. 1998. "New institutionalism and the governance of the Single European Market," Journal of European Public Policy 5 (3): 365-386.

Checkel, Jeffrey T. 2001. "Why Comply? Social Learning and European Identity Change," International Organization 55 (3): 553-588.

Czech Republic, Ministry of Foreign Affairs. 2013. Main pillars of Czech Industry. Accessed August 20, 2013. http://www.czech.cz/en/Business/Economic-facts/Main-pillars-ofCzech-industry

Dandashly, Assem. 2015. "The Political Impediments to Euro Adoption in Poland," Problems of Post-Communism 62 (5): 287-298

Dandashly, Assem and Amy Verdun. 2016. "Euro Adoption in the Czech Republic, Hungary and Poland: Laggards by Default and Laggards by Choice," Comparative European Politics, forthcoming.

Die Zeit. 2003. "Der EU-Beitritt ist nicht unser Traum'-Europa als Bedrohung der Demokratie: Ein ZEIT-Gespräch mit dem tschechischen Präsidenten Václav Klaus,” April 17. Accessed on December 4, 2014. http://www.zeit.de/2003/17/V_Klaus?page=all

Dyson, Kenneth. 2007. "Euro Area Entry in East-Central Europe: Paradoxical Europeanization and Clustered Convergence," West European Politics 30 (3): 417-442.

Elster, J., C. Offe, and U. K. Preuß. 1998. Institutional Design in Post-Communist Societies: Rebuilding the Ship at Sea. Cambridge: Cambridge University Press. 
EUbusiness. 2013. "Slovak car sector expects moderate growth this year," April 17. Accessed on August 27, 2013. http://www.eubusiness.com/news-eu/slovakia-economy.oli

EUobserver. 2013. “Bye-bye Mr Klaus! Bye-bye euroscepticism?” January 25. Accessed June 20, 2013. http://euobserver.com/opinion/118860

European Commission. 2008. "Introduction of the Euro in the New Member States: Analytical Report," Eurobarometer, Brussels.

- 2009. "Introduction of the Euro in the New Member States: Analytical Report," Eurobarometer, Brussels.

—. 2010a. "Introduction of the Euro in the New Member States: Analytical Report," Eurobarometer, Brussels.

- 2010b. The euro area, 2010 Public attitudes and perceptions-Analytical report, Flash Eurobarometer 306, Brussels.

- 2012. Public Opinion in the European Union, Standard Eurobarometer 77/Spring, Brussels.

- 2013a. Public Opinion in the European Union, Standard Eurobarometer 79, Brussels.

- 2013b. Introduction of the euro in the more recently acceded Member States, Flash Eurobarometer 377, Brussels.

- 2014a. Introduction of the euro in the more recently acceded Member States, Flash Eurobarometer 400, Brussels.

—. 2014b. The Euro Area, Flash Eurobarometer 405, Brussels.

Eurostat. 2015. http://ec.europa.eu/eurostat

Feldstein, Martin. 2011. "Václav Klaus and the Euro," Cambridge, Massachusetts. March. Accessed December 4, 2014. http://www.nber.org/feldstein/essaysinhonorofVáclavKlaus.pdf

Gilbert, Emily and Eric Helleiner (eds). 1999. Nation-States and Money: The Past, Present, and Future of National Currencies. London: Routledge.

Goldman, Minton F. 1999. Slovakia since Independence: A Struggle for Democracy. Westport, CT: Praeger Publishers.

Haas, Peter M. 1992. "Epistemic Communities and International Policy Coordination," International Organization 46 (1): 1-35. 
Hanley, Sean. 2007. The New Right in the New Europe: Czech Transformation and Right-wing politics, 1998-2006. London and New York; Routledge.

Haughton, Tim. 2009. 'For Business, for Pleasure or for Necessity? The Czech Republic's Choices for Europe," Europe-Asia Studies 61 (8): 1371-1392.

- 2010. "Vulnerabilities, Accession Hangovers and the Presidency Role: Explaining New EU Member States' Choices for Europe," Working Paper Series 68, Centre for Russian and East European Studies, University of Birmingham, Birmingham, UK.

Heipertz, Martin and Amy Verdun. 2010. Ruling Europe: Politics and Theory of the Stability and Growth Pact. Cambridge: Cambridge University Press.

Helleiner, Eric. 2003. The Making of National Money: Territorial Currencies in Historical Perspective. Ithaca: Cornell University Press.

Holeček, Jaroslav. 2013. Automotive industry Association of Slovak Republic-ZAP SR. Accessed August 20, 2013. http://www.pwc.com/hu/hu/gyor/assets/jaroslav_holecek.pdf

Holý, Ladislav. 1996. The Little Czech and the Great Czech Nation. Cambridge: Cambridge University Press.

Huelshoff, Michael G. 1994. "Domestic Politics and Dynamic Issue Linkages-A Reformulation of Integration Theory,” International Studies Quarterly 38 (2): 255-279.

Hurník, Jaromír, Zdenìk Tůma, and David Vávra .2010. "The Euro Adoption Debate Revisited: The Czech Case," Czech Journal of Economics and Finance 60 (3): 194-212.

Jevčák, Anton. 2011. "Did nominal exchange rate flexibility matter during the global recession? A Czech and Slovak case study," ECFIN Economic Brief, No. 14.

Johnson, Juliet. 2003. "Agents of Transformation: The Role of the West in Post-Communist Central Bank Development," The National Council for Eurasian and East European Research (NCEEER), Title VIII Program, Chicago: Loyola University, 1-33.

—. 2006. "Two-Track Diffusion and Central Bank Embeddedness: The Politics of Euro Adoption in Hungary and the Czech Republic," Review of International Political Economy 13 (3): 361-386.

- 2008. "The Remains of Conditionality: The Faltering Enlargement of the Euro Zone," Journal of European Public Policy 15 (6): 826-842.

Klaus, Václav. 2003. The Future of Euro: A View of A Concerned Outsider, Prague. Accessed December 4, 2014. http://www.klaus.cz/clanky/439 
Ladrech, Robert. 1994. "Europeanization of Domestic Politics and Institutions: the Case of France," JCMS: Journal of Common Market Studies 32 (1): 69-88.

National Bank of Slovakia. 2003. "Strategy of the Slovak Republic for Adoption of the Euro," BIATEC XI, 8/2003.

- 2006. The Effects of Euro Adoption on the Slovak Economy, Bratislava, March.

National Bank of Slovakia and Ministry of Finance. 2003. Strategy of Adopting the Euro in SR, Bratislava, July.

- 2004. Specification of the Euro Adoption Strategy, Bratislava, September.

National Bank of Slovakia and Ministry of Finance. 2005. National Euro Changeover Plan for the Slovak Republic, Bratislava, July.

The New York Times. 2009. "Neighbor's Shadow Still Large in Slovakia." July 3. Accessed November 15, 2015. http://www.nytimes.com/2009/07/04/business/global/04slovakia.html? r=0

The Observatory of Economic Complexity (OEC). 2015. "Czech Republic" http://atlas.media.mit.edu/en/profile/country/cze/. Last accessed on November 26, 2015.

OECD. 2000. Economic Survey: Czech Republic, Paris: OECD.

- 2009. Ekonomický prehlad Slovenskej republiky [Economic overview of the Slovak Republic], Paris. Accessed September 14, 2012. http://www.oecd.org/economy/economicsurveysandcountrysurveillance/42116243.pdf

Pechova, Andrea. 2012. "Legitimising discourses in the framework of European integration: The politics of Euro adoption in the Czech Republic and Slovakia," Review of International Political Economy 19 (5): 779-807.

Prague Daily Monitor. 2011. "Poll: Only 15\% of Czechs are for euro adoption." March 4. http://praguemonitor.com/2011/03/04/poll-only-15-czechs-are-euro-adoption.

Risse, Thomas. 2003. "Nationalism and Collective Identities. Europe versus the Nation-State?" in P. Heywood, E. Jones and M. Rhodes (eds), Developments in West European Politics. London: Palgrave Macmillan, 77-93.

Schimmelfennig, Frank and Ulrich Sedelmeier. 2004. "Governance by Conditionality: EU Rule Transfer to the Candidate Countries of Central and Eastern Europe," Journal of European Public Policy 11 (4): 661-679. 
- 2005. "Introduction: Conceptualizing the Europeanization of Central and Eastern Europe," in F. Schimmelfennig and U. Sedelmeier (eds), The Europeanization of Central and Eastern Europe. Ithaca, NY: Cornell University Press, 1-28.

Správy. 2013. "Slovensko je už svetová vel'moc vo výrobe áut.” April 1. Accessed August 26, 2013. http://spravy.pravda.sk/ekonomika/clanok/276116-slovensko-je-uz-svetovavelmoc-vo-vyrobe-aut/

Statistical Office of the Slovak Republic. 2006. "Number and share of valid votes cast for political parties.” Accessed on September 14, 2012.

http://app.statistics.sk/nrsr_2006/angl/obvod/results/tab3.jsp

Treaty of Accession. 2003. Official Journal of the European Union, L 236, Vo 46, 23 September.

Verdun, Amy. 1999. "The role of the Delors Committee in the creation of EMU: an epistemic community?" Journal of European Public Policy 6 (2): 308-328.

-2000. European Responses to Globalization and Financial Market Integration: Perceptions of Economic and Monetary Union in Britain, France and Germany. Houndmills: Palgrave/New York: St. Martin's Press.

Vliegenthart, Arjan and Laura Horn. 2007. "The role of the EU in the (trans)formation of corporate governance regulation in Central Eastern Europe - The case of the Czech Republic," Competition and Change 11 (2): 137-154.

Walt, Stephen M. 1998. "International Relations: One World, Many Theories," Foreign Policy 110, 29-46.

World Bank Data. 2015. http://data.worldbank.org 
Published by the Centre for European Studies at Carleton University, Ottawa, Canada Available online at: journals.carleton.ca/rera/index.php/rera

RERA is an electronic academic peer-reviewed journal that publishes graduate, post-graduate, and young scholarly works. Topics relate to the European Union, its Member States, the former Soviet Union, and Central and Eastern Europe. The journal is a joint project supported by the CanadaEurope Transatlantic Dialogue - a cross-Canada research network supported by the Social Sciences and Humanities Research Council of Canada (SSHRC) - along with the Institute of European, Russian and Eurasian Studies (Carleton University) and its associated research unit, the Centre for European Studies.

RERA aims to provide an accessible forum for research, to promote high standards of research and scholarship, and to foster communication among young scholars.

\section{Contact:}

Carleton University

The Centre for European Studies

1103 Dunton Tower

1125 Colonel By Drive

Ottawa, ON K1S 5B6

Canada

Tel: +01 613 520-2600 ext. 3117; E-mail: rera-journal@ carleton.ca

\section{Creative Commons License}

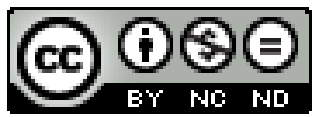

creativecommons.org/licenses/by-nc-nd/3.0

This Working Paper is licensed under a Creative Commons Attribution-Non-CommercialNo Derivs 3.0 Unported License (CC BY-NC-ND 3.0).

Articles appearing in this publication may be freely quoted and reproduced, provided the source is acknowledged. No use of this publication may be made for resale or other commercial purposes.

ISSN: $1718-4835$

(C) 2015 The Authors 